NBER WORKING PAPER SERIES

\title{
THE IMPACT OF EMPLOYEE STOCK OPTIONS ON THE EVOLUTION OF COMPENSATION IN THE 1990s
}

\author{
Hamid Mehran \\ Joseph Tracy \\ Working Paper 8353 \\ http://www.nber.org/papers/w8353
NATIONAL BUREAU OF ECONOMIC RESEARCH
1050 Massachusetts Avenue
Cambridge, MA 02138
July 2001

Federal Reserve Bank of New York. We benefitted from helpful discussions with Alan Marcus, Elizabeth Keating and comments from seminar participants at the Department of Labor and the Georgetown University Law Center Conference on "Contracts with Highly Skilled Workers." John Campbell, Martin Lettau and John Graham kindly provided us with a portion of their data. We thank Nathanial Baum-Snow and Dan Burdick for their excellent research assistance. We also thank Hewitt Associates for providing summaries of their data and technical assistance, and Thermo Electron for providing us with the information on details of its employee stock options program and reporting. The views expressed herein are those of the authors and not necessarily those of the National Bureau of Economic Research, the Federal Reserve Bank of New York or the Federal Reserve System.

(C) 2001 by Hamid Mehran and Joseph Tracy. All rights reserved. Short sections of text, not to exceed two paragraphs, may be quoted without explicit permission provided that full credit, including $(\mathbb{C}$ notice, is given to the source. 
The Impact of Employee Stock Options on the Evolution of Compensation in the 1990s Hamid Mehran and Joseph Tracy

NBER Working Paper No. 8353

July 2001

JEL No. J33, J38, G10

\begin{abstract}
$\underline{\text { ABSTRACT }}$
Between 1995 and 1998, actual growth in nominal compensation per hour (CPH) accelerated from approximately 2 percent to 5 percent. Yet as labor markets continued to tighten in 1999, the growth in $\mathrm{CPH}$ paradoxically slowed. In this article, we attempt to solve this aggregate wage puzzle by exploring whether changes in pay structure - specifically, the increased use of employee stock options - can account for the behavior of CPH in the late 1990s. CPH reflects employee stock options on the date they are realized rather than on the date they are granted. When we recalculate $\mathrm{CPH}$ growth to reflect the value of current stock options when they are granted - rather than their value when they are realized - we find that our adjusted CPH measure accelerated in each year from 1995 to 1999.
\end{abstract}

Hamid Mehran

Federal Reserve Bank of New York

33 Liberty Street

New York, NY 10045
Joseph Tracy

Federal Reserve Bank of New York

33 Liberty Street

New York, NY 10045

and NBER

joseph.tracy@ny.frb.org 
The decade of the 1990s was remarkable in many ways. This decade produced the longest running U.S. economic expansion. A byproduct of this continued economic growth was a sharp tightening of the U.S. labor market. The growing scarcity of available workers raised the concern that accelerating wage demands would develop which might lead to renewed inflation. Figure 1 shows the growth rate of nominal compensation per hour $(\mathrm{CPH})$ and its relationship to the prime age male unemployment rate during the 1990s. ${ }^{1}$ Two "wage puzzles" exist during the 1990s. The first relates to the period from 1992 to 1995 when compensation growth declined at the same time that the unemployment rate was rapidly falling. One explanation is that "worker insecurity" early in the expansion accounted for the tepid pay demands during this period. ${ }^{2}$ From 1995 to 1998, compensation growth accelerated as the unemployment rate broke through the four percent barrier. However, the second wage puzzle emerges in 1999 when compensation growth fell back below the five percent level despite the continued tightening in the labor market during the year. What explains these two wage puzzles?

In this paper, we explore whether changes in the structure of pay can help explain the behavior of $C P H$ during the 1990s. Labor markets have changed considerably over the last twenty years. Workers today receive a higher portion of their total compensation in nontraditional forms such as profit-sharing and stock options. ${ }^{3} \mathrm{CPH}$ captures profit-sharing and stock options. However, stock options are reflected in total compensation on the date they are exercised, not on the date they are granted. As we discuss below, there can be several years between the grant and exercise dates for stock options. This raises the possibility that the growing use of stock options may be affecting the timing of when tight labor markets are reflected in $\mathrm{CPH}$ growth.

We bring the existing data to bear on the question of how the use of stock options is affecting the growth in $C P H$. Given data limitations, we will focus primarily on the second pay

${ }^{1} \mathrm{CPH}$ is the most comprehensive of all U.S. pay measures. It captures wage and salary income, tips and overtime, paid leave and severance pay, payments in kind, benefits, bonus and profit-sharing payments, and realizations of stock options.

${ }^{2}$ See Farber (1997) and Manski and Straub (2000).

${ }^{3}$ See Bell \& Neumark (1993), Bell \& Kruse (1995), Cohn (1999), Duca (1998), Epstein (1999) and Lebow et al (1999). 
puzzle. While we can provide an educated assessment of the likely impact of stock options on the dynamics of $\mathrm{CPH}$, there is a clear need for more data. We find evidence that stock options may have had an appreciable impact on $C P H$ in the late 1990s. When we recalculate compensation to reflect current stock option grants instead of current realizations, we find that there was likely no downturn in the growth in $C P H$ in 1999.

The paper is organized as follows. The next section lays out the essential institutional details regarding employee stock options necessary for our empirical work. Empirical models of the stock option grant and realization decisions are presented and discussed in the third section. In the fourth section, we use these estimates to assess the impact of employee stock options on compensation per hour. The final section discusses some general implications of stock options for the labor market.

\section{Accounting for Stock Options}

Employee stock options (ESOs) are the right to purchase a given number of shares of company stock at the "strike" price between the vesting date and the expiration date of the options. ${ }^{4}$ The vesting period for an option is the interval of time between when a company grants the option to the employee and when the employee can first exercise the option. If the current market price for a vested option exceeds the strike price, then the option is "in-the-money." If inthe-money options are exercised (that is, the employee decides to purchase the underlying shares), then the gain to the employee is the difference between the current market price and the strike price times the number of shares exercised. ${ }^{5}$ If the current market price for a vested option is below the strike price, then the option is "out-of-the-money." While out-of-the-money options would have no current value if exercised, they still have positive "option value," which reflects

${ }^{4}$ See Murphy (1999) for a discussion of the structure of ESO plans.

${ }^{5} \mathrm{~A}$ common practice is for a cashless transaction to occur using the services of a third-party. The third-party makes a short-term loan to the employee to cover the cost of purchasing the exercised options at the strike price. The shares are then immediately sold back out into the market and the loan is paid off, with a fee going to the third-party. 
the possibility that the future market price of the stock may rise above the strike price prior to their expiration date.

ESOs can be structured as either "incentive stock options" (ISO) or "nonqualified stock options" (NQSO). ISOs must satisfy certain restrictions defined by the Internal Revenue Service which do not apply to NQSOs. ${ }^{6}$ The primary advantages of ISOs to employees is that the income derived from the exercise of the options is taxed as a capital gain rather than as ordinary income, and the tax is levied when the underlying shares are sold rather than when the shares are exercised. Offsetting this tax gain to employees from ISOs is the loss of a tax deduction to the firm. In contrast to ISOs, the income gain from NQSOs is treated for tax purposes as ordinary income to the employee as of the exercise date, and the company can deduct this cost as a labor expense. Employers are required to file quarterly reports (ES202) that list all taxable sources of income paid to their employees including realized NQSOs. The ES202 reports are used as an input into total compensation. However, these reports do not break out the gain from NQSOs from other sources of compensation. NQSOs became the dominant type of ESO following the reduction in marginal income tax rates in 1986.

In January 1993, the Security and Exchange Commission (SEC) started requiring public firms to disclose in their proxy statements both the level of stock option grants and the option exercise activity to their top five executives. The SEC also required that companies report their executive compensation for the two previous years in the annual filing with the agency. Starting in 1991, then, it is possible to collect detailed information on public company stock option programs for top management. Firms could value these option grants using any pricing methodology. The dominant method used in practice is the Black-Scholes pricing formula.

ESOs differ in many important ways from traded stock options (TSOs). The most important difference is that they are nontradeable. An employee can exercise a vested in-themoney option, but can not sell the option to an investor. An implication is that both the employee's valuation of the option and the timing of the exercise decision will be affected by the employee's risk tolerance. An employee with a significant amount of wealth tied up in company

\footnotetext{
${ }^{6}$ Internal Revenue Code Section 422.
} 
stock options has a strong interest in diversifying the risk from movements in the value of the company stock. With TSOs, the employee could simply sell some of the options in the market to another investor, an action which transfers but does not diminish the underlying value of the options. With ESOs, the employee would have to exercise the options in order to diversify their risk. $^{7}$ This creates an incentive for early exercise of vested ESOs, which reduces their overall value by forgoing their remaining option value. Huddart and Lang (1996) show that workers tend to exercise ESOs soon after their vesting dates, and that this early exercise sacrifices roughly half of the value implied by the Black-Scholes pricing methodology (which is designed to price a TSO).

Two other distinctions arise when comparing ESOs and TSOs. As mentioned earlier, ESOs are subject to vesting requirements and tend to have a significant time period until expiration. A variety of vesting schedules are used in practice, with the majority of plans incorporating vesting over two to five years. ${ }^{8}$ In addition, an employee must exercise any vested in-the-money ESOs prior to leaving a firm. Any non-vested or out-of-the-money ESOs must be forfeited upon termination of the employment relationship. This creates an additional reason for early exercise of ESOs. ${ }^{9}$

${ }^{7}$ For ISOs there is a minimum holding period on the underlying stock which compounds the diversification problem. No similar restriction applies to NQSOs.

${ }^{8}$ A Hewitt Associates study of 74 plans in 1998 found that $35 \%$ of the plans used Cliff vesting (where all shares vest at the same specified time) with one and three years being the most frequent vesting times, $45 \%$ of the plans used uniform vesting (where share vest at a uniform rate over the vesting period) with three and four years being the most frequent vesting times and the remaining $20 \%$ either used mixed vesting or provided no information (TCM Data 1998). The most common expiration date is ten years after the grant date.

${ }^{9}$ This feature of ESOs makes them a useful tool for reducing employee turnover. Mehran and Yermack (1999) document that the probability of a voluntary departure by a CEO is inversely related to the length of the stock option vesting schedule. They also document that the higher the ratio of deferred compensation to current pay, the less likely a CEO is to leave voluntarily. 


\section{Measuring the Importance of Employee Stock Options}

Standard and Poor's (S\&P) ExecuComp is our primary data source. ExecuComp includes annual data from proxy statements for the five highest paid executives in three cohorts of firms: the S\&P 500, S\&P MidCap 400 and S\&P Small Cap $600 .{ }^{10}$ S\&P makes some adjustments to the firms in the data base each year. Our pooled sample which covers the period from 1992-1999 comprises a total of around 2,000 companies. We make extensive use three specific items from the ExecuComp data: the total number of new grants to all employees, the number of grants and their value going to the top five executives and the value of exercised options by the top five executives. We calculate the total value of all new grants in a year by scaling up the value of the grants to the top five executives by the ratio of the total number of options granted to the number of options granted to the top five executives. ${ }^{11}$

The ExecuComp data is useful for examining general trends in the use of employee stock options during the 1990s. For example, over the decade stock options became the dominant component of an executive's compensation package. We illustrate this remarkable change using two measures of the relative importance of executive stock options. The first is the ratio of the grant value of new options in a year divided by the executive's base salary and cash bonus. The second is the ratio of the income gain from stock option realizations in a year divided by the executive's base salary and cash bonus. Figure 2 shows the averages for these two ratios from 1992 to 1999 . Early in the 1990 s, both ratios indicate that stock options were typically smaller than an executive's base salary and cash bonus. By 1996, both ratios equaled or exceeded one. Two years later, continued rapid growth in the expansion of executive stock option programs had pushed both ratios above two, with new grants averaging around $250 \%$ of an executives base

\footnotetext{
${ }^{10}$ The median real market value is $\$ 8.3$ billion for the S\&P 500 firms, $\$ 1.7$ billion for the S\&P MidCap firms and $\$ 0.4$ billion for the S\&P Small Cap firms.

${ }^{11}$ Starting in 1994, Exеси Сотр recalculates the grant value of a company's new options using a consistent set of assumptions on the interest rate, implied stock return volatility, and expected duration of the option. Company Handbooks on ESO plans typically do not make any distinction between executive and non-executive stock option plans. Therefore, we to assume that the Black-Scholes value of an option granted to an executive and to a non-executive is the same.
} 
salary and bonus. In 1999, the grants ratio leveled off while there was a sharp reduction in the realization ratio. ${ }^{12}$

An important related question is whether the use of stock options is also filtering its way down through the ranks of company pay structures. The ExecuComp data allow us to track the distribution of the percent of total new stock option grants that are awarded to the top five management. While this is a very restrictive view of the diffusion of stock options down through the corporate ranks, it has the advantage of providing some sense of recent trends. Figure 3 shows the equally weighted $25^{\text {th }}, 50^{\text {th }}$ and $75^{\text {th }}$ percentiles of these top five percentages from 1992 to 1999. Despite the dramatic rise in the use of stock options for executives, there has actually been a slight decline in the fraction of new stock option grants directed toward upper management. This indicates that there has also been a commensurate increase over the 1990s in the use of stock options for employees below the top management level.

Given the rapid rise in the use of stock options, it is interesting to speculate on the impact that stock options are having on aggregate compensation growth in the private sector. As noted earlier, aggregate compensation reflects NQSOs when they are realized rather than when they are granted. Unfortunately, there is no currently collected data that permit the direct measurement of the total size of stock option grants or realizations in the labor market. The alternative is to estimate total stock option grants and NQSO realizations by year. The growth rate of $C P H$ net of the income from stock option realizations can then be constructed and contrasted with its actual growth rate. In addition, the cash value of new stock option grants can be added into this net of realizations $\mathrm{CPH}$ measure to arrive at a more accurate measure of current labor market pay conditions. We now turn our attention to implementing this approach.

The private non-farm sector consists of publically traded and private firms. Over the past five years, public firm have accounted for between forty-seven and fifty percent of employment in the private non-farm business sector. The ExecuComp data consists entirely of publically

\footnotetext{
${ }^{12}$ There is no general agreement as to what has caused the popularity of stock options in the 1990's. Murphy (1999) presents a behavioral discussion. Hall and Liebman (1998) examine the role of taxes where under IRC Section 162(m) compensation above one million dollars in not deductible unless it is performance-based. Of the 1,672 firms on ЕxecuСomp in 1998, 1,566 reported paying less than a one million dollar salary for their CEOs.
} 
traded firms, and in 1998 covered roughly $46 \%$ of the total employment in public firms. ${ }^{13}$ Detailed characteristics of publically traded firms are available from the COMPUSTAT data, and equity returns for these firms are available from the CRSP data. For private firms, we have no similar data on their characteristics, nor do we have any details of stock option plans in which to draw any inferences. However, a recent Bureau of Labor Statistics study found that the incidence of stock options in privately held firms in 1999 was significantly below that for publically held firms. ${ }^{14}$ Based on this evidence we will focus our analysis exclusively on public firms.

The basic question, then, is how best to use the ExecuComp data to estimate total stock option grants and realizations for publically held firms. The simplest approach would be to assume for each year that all employees in these firms that are outside of the ExecuComp sample are awarded new stock option grants and realize vested stock options at the average rate observed in that year for employees covered in the ExecuComp data. This approach, however, ignores potentially important variations across firms in their use of stock options that relates to the characteristics of the firm. Taking this variation into account may provide a more accurate estimate of the overall impact of stock options on total compensation.

\section{Determinants of Stock Option Grants}

We start with the problem of estimating stock option grants, since the volume of prior stock option grants is likely to be an important predictor of current realizations. For firms in the ExecuComp sample, we can calculate the Black-Scholes value of the total ESO grants made in the year. ${ }^{15}$ While we are interested in understanding the determinants of the firm's decision on the total amount of new grants to make in a year, it is useful to look toward the executive compensation literature for guidance on an appropriate empirical specification.

${ }^{13}$ This is based on the comparison of COMPUSTAT employment for ExecuComp firms in 1998 to total employment of COMPUSTAT firms in the same year.

${ }^{14}$ See BLS, October 11, 2000.

${ }^{15}$ ExecuComp reports the Black-Scholes value of new grants to each of the top five executives, and the ratio of their grants to the total new grants made in the year. From this information, we can back out the total Black-Scholes grant value. 
The literature on executive compensation starts with the premise that optimal compensation policies should address agency problems between the firm's managers and its equity and debt holders. The two methods for ameliorating these agency problems are monitoring and incentives. ${ }^{16} \mathrm{~A}$ general prediction is that stock options will be more extensively used when agency costs are high and monitoring is difficult. In addition, the accounting treatment of stock options discussed earlier suggests that firms may also use stock options for tax or liquidity reasons.

We include several variables to control for expected agency costs. Monitoring may become difficult when a firm has significant growth opportunities. Information asymmetries may arise from these opportunities which make evaluating the managers' investment choices more difficult [e.g., Mehran (1992), Smith \& Watts (1992) and Bizjak et al (1993)]. Stronger incentives, then, are needed to compensate for the monitoring difficulties. These additional incentives can be provided by increasing the share of stock options in total compensation. We measure a firm's growth opportunities using its market-to-book value (MVBV). The prediction is that stock option grants will be positively related to a firm's MVBV.

Monitoring managers is also difficult in an environment where there is a significant amount of noise regarding the firm's performance [Lambert \& Larcker (1987)]. In such an environment, a higher pay-performance sensitivity is warranted. Yermack (1995) proxies this using the ratio of the relative variability of accounting returns as compared to stock returns. We focus just on the variability of the stock returns over the prior year. The prediction is that higher stock return variability will lead to increased use of stock options. However, higher stock return variability also increases the manager's risk exposure, which should lead to a higher risk premium to compensate the manager for this added risk. ${ }^{17}$ This risk premium increases the relative price to the firm of using stock options versus cash compensation, which may induce the

${ }^{16}$ Our discussion borrows heavily from Yermack (1995).

${ }^{17}$ While volatility always raises the option value of TSOs, Lambert, Larcker, and Verrecchia (1991) and Kulatilaka and Marcus (1994) show that increased volatility can lower the value of ESOs, especially for more risk averse employees. 
firm to substitute away from stock options in its pay structure. The overall effect, then, of stock return variability on the use of stock options is ambiguous.

Capital structure may also exert an important influence on a firm's compensation system. Stock options, by increasing managers' pay-performance sensitivity, may encourage managers to pursue riskier investment strategies that tend to favor equity holders over debt holders. If this shift in investment strategies is anticipated by bond holders, then increased reliance on stock options will give rise to a debt premium which differentially impacts highly leveraged firms [John \& John (1993)]. To reduce this agency cost of debt, highly leveraged firms may choose to scale back their use of stock options. This should lead to an inverse relationship between a firm's leverage and its reliance on stock options. ${ }^{18}$

To help control for any firm life-cycle effects on the use of stock options, we control for a firm's age which we measure as the number of years the firm's stock has been traded. If young firms tend to be more cash flow constrained, then we would expect them to rely more heavily on stock options. When a firm issues new stock options it typically incurs no current expense, rather the expense is shifted into the future when the stock options are realized. Workers, however, value these new stock options and are willing to accept lower current cash compensation as a consequence. This should lead to a negative relationship between firm age and the granting of stock options. We also directly proxy for cash flow constraints using an indicator variable for whether the firm has a net operating loss in the current year.

Our remaining firm-specific variables include measures of recent performance and firm size. We measure firm performance using the firm's return on assets (ROA). We use the size of the firm's assets and employment to control for possible scale effects. Finally, we include twodigit industry effects and year effects to control for any remaining differences across industries and time in the pattern of stock option grants.

Our estimation results for stock option grants are presented in Table 1. Summary statistics are provided in Appendix B. For most of our control variables of interest, we divide the range of

\footnotetext{
${ }^{18}$ More specifically, the prediction pertains to the relative portion of an executive's compensation that is stock based. Our dependent variable is the total amount of stock options granted, rather than the ratio of total stock option grants to total compensation.
} 
the variable into quartiles and create indicator variables for the upper three quartiles. The coefficient on an indicator variable should be interpreted as the difference is the use of stock option grants between a firm with a value of the indicated variable in the specified quartile and a similar firm with a value of the indicated variable in the bottom quartile (holding all values for other variables at their sample means)

The use of stock options varies with firm performance and firm size. Firms with high ROA tend to grant fewer new stock options. For example, grants for firms performing at or above the median in ROA tend to be around $35-40 \%$ below the poorest performing firms. Stock option grants tend to increase with the firm size as measured by employment and total assets. The employment relationship only applies to the top size quartile, while the asset relationship holds throughout the size range, is quite large in magnitude but is imprecisely estimated. Core and Guay's (1999) found that executive stock and option incentives are positively related to firm size as measured by equity value.

We find empirical support for the agency cost of debt constraint on employee stock options. Controlling for other factors, highly leveraged firms tend to pay out fewer new stock option grants. Firms in the highest quartile of leverage have new grants that are on average $26 \%$ below the level of firms in the lowest quartile of leverage. This is in contrast to Yermack's (1995) empirical findings.

Monitoring problems arising from potential market opportunities and noisy environments also play an important role in determining the flow of new stock option grants. Firms with higher MVBV tend to have much more aggressive stock option programs, as evidenced by consistently higher flows of new stock option grants. This effect is especially pronounced for firms in the top MVBV quartile who are predicted to have on average a 300 percent larger flow of stock option grants than for firms in the bottom MVBV quartile. Higher stock return volatility reduces the magnitude of a firm's stock option grants. These findings are consistent with the existing empirical literature [see Core and Guay (1999), (2000)].

We also find support for the prediction that firms facing cash flow constraints substitute stock options for cash compensation. The data suggest that firms experiencing a net operating loss in a given year have stock option grants that are 24 percent higher than similar firms with 
operating profits. ${ }^{19}$ In addition, younger firms tend to rely more heavily on the use of stock options in their compensation structure. A ten year increase in firm age is associated with an 8 percent decline in stock option grants.

\section{Determinants of Stock Option Realizations}

The ExесиСотр data report the stock option realizations for each of the top five executives. What is not reported is the total stock option realizations generated by the other employees. To estimate total realizations, we assume that the time pattern of stock option realizations by the top five executives can be used to proxy for the time pattern of realizations for the remaining employees. ${ }^{20}$ Specifically, we calculate the total realizations in the year for a firm by scaling up the realizations by the top five executives using the ratio of total grants to top five grants from two years earlier. ${ }^{21}$

The empirical specification for a firm's total stock option realizations is motivated in part by the characteristics of ESO plans. In any given year, an employee has the right to realize any vested stock options. As previously noted, there is a strong tendency for employees to exercise options close to their vesting dates. While vesting schedules vary across firms, the typical vesting rules imply that it would be important to control for stock option grants from two to five year prior to the current year. Given the short time span covered by the ЕхесиСотр data, we compromise and include only stock option grants from two years prior to the current year.

\footnotetext{
${ }^{19}$ As a robustness check we also used the firm's "before financing" marginal tax rate [see Graham (1996) (2001)]. We find that both net operating loss and marginal tax rates generate the predicted sign and are statistically significant. However, marginal tax rates were missing for roughly $15 \%$ of our COMPUSTAT sample, so we proceed using just the net operating loss.

${ }^{20}$ The time pattern of exercise for executives may differ from other employees for two reasons. First, executives have private information about their firm's prospects which can alter the timing of their exercise decision. Second, footnotes in companies' proxy statements typically reveal that top executives may exercise their options sooner than the normal vesting schedules would permit if certain financial conditions are met. Huddart and Lang (1996) find that the exercise decisions by top management as compared to other employees is less sensitive to recent stock returns and return volatility.

${ }^{21}$ Ideally, we would like to use a weighted average of these ratios based on the typical vesting pattern for ESOs. This is precluded by the short time period covered by the ExecuComp sample.
} 
Vested stock options will be exercised only if they are in-the-money. Since the option strike price is typically set equal to the market price on the grant date, the cumulative stock return during the vesting period will determine whether an option is in-the-money on the date it vests. If a firm makes grants to employees over several years and uses a staggered vesting schedule, then the appropriate stock return to examine would be a weighted average of different cumulative stock returns over the various vesting periods. Since we lack the detailed data necessary to calculate this particular stock return, we will use the firm's cumulative stock return over the prior two years as our proxy.

A prominent feature of stock option realizations data is that in a given year many firms experience no realizations, even if these firms have continuously made grants over the past several years. In our sample of around 5,189 firm/year observations for which we have complete data on all of our control variables, $32 \%$ involve no realizations by the firm in that year. To account for the high frequency of zero realizations in the data, we use a generalized Tobit specification. Details on the generalized Tobit model are provided in Appendix A.

The generalized Tobit results are presented in Table 2. For ease of interpretation, we convert the generalized Tobit coefficients into three marginal effects: the implied impact of a variable on (1) the probability that a firm experiences a positive realization in the year, on (2) the percent change in the expected log realizations conditional on a positive realization, and on (3) the percent change in the unconditional expected log realizations.

The level of prior grants and the two year cumulative stock return both have positive and significant effects on current realizations. Higher prior grants of stock options raise both the probability that a firm has positive realizations in the current year [column (1) of Table 2] and the expected magnitude of these realizations conditional on the realizations being positive [column (2) of Table 2]. Holding constant the level of prior grants, current realizations are sharply increasing in the firm's two-year cumulative stock return. Like prior grants, higher stock returns increase both the incidence and magnitude of current realizations. These findings are consistent with the results of prior case studies [Huddart \& Lang (1996)].

While larger firms are more likely to experience positive stock option realizations in a year, firm size as measured by employment has no significant impact on the conditional 
magnitude of the realizations. Similarly, holding constant our other control variables, the degree of firm leverage has no significant impact on realizations. Stock option realizations show a strong positive relationship with a firm's MVBV. This reflects both a positive effect of MVBV on the incidence and magnitude of realizations. Finally, higher stock risk raises the likelihood of a firm experiencing positive realizations, but does not have any further impact on the magnitude.

\section{The Impact of Stock Options on CPH}

We are now at a point where we can assess the overall impact of stock options on aggregate $C P H$. We use our earlier estimates to predict stock option grants and realizations for all COMPUSTAT firms. We use actual firm data on grants and realizations where reported in the ExесиСотр sample. For COMPUSTAT firms that are not in the ExecuComp sample where we have a complete set of control variables (where we use predicted instead of actual lag stock option grants), we predict their stock option realizations using the estimated model presented in Table 2. For the remaining firms in COMPUSTAT where we have missing data problems for one or more of our control variables, we impute their stock option realizations. ${ }^{22}$ We aggregate these actual and estimated stock option grants and realizations across all publically traded firms, and then multiply by the assumed fraction of ESOs that comprise NQSOs. ${ }^{23}$ This provides our estimate of the total income generated from NQSOs in that year.

Table 3 shows total compensation for the private non-farm business sector, our estimates of total NQSO grants and realizations, and the growth rates of all three for the years 1995

\footnotetext{
${ }^{22}$ For firms with one or two missing values for our control variables, we impute these missing values by regressing the variables in question on all other control variables using the estimation sample which has no missing values. We then predict their grants and realizations using these estimated values for the missing right-hand-side variables and actual data for the remaining control variables. For firms with chronic missing data problems, we leave their grant and realization values missing. We then scale up by 1-digit industry our estimates to cover all public firms by taking our in-sample average grant and realizations per employee and multiplying this by the ratio of total public firm employment in that industry to our in-sample public firm employment in that industry.

${ }^{23}$ We assume that $82 \%$ of ESOs represent NQSOs, and that this fraction is constant over our sample period [see Hewitt Associates (1998)]. When reporting the value of new NQSO grants, we scale down first by the $82 \%$ and then by an additional $50 \%$ to reflect the likely overestimate of the value by the Black-Scholes methodology [see Huddard and Lang (1996)].
} 
through 1999. The findings are presented both on an aggregate and on a per worker basis. The data indicate that in the mid-nineties stock option grants and realizations amounted to less than one percent of total compensation. However, the growth rates of both have significantly exceeded the growth rate of compensation. For example, in 1998 stock option grants and realizations grew by 56 percent and 53 percent respectively, whereas total compensation grew by 8 percent. Over the five years from 1995 to 1999, stock options realizations per worker more than doubled from $\$ 395$ to $\$ 1,068 .^{24}$

The rapid rate of increase in the magnitude of employee stock options raises the possibility that they may have had a significant impact on the growth of $C P H$ in recent years. The growth in $\mathrm{CPH}$ can be expressed as a weighted average of the growth in stock option realizations per hour and the growth in other compensation per hour. The weight on the growth in stock option realizations per hour is the share of stock option realizations in that year to total compensation. Despite the small weight given to stock option realizations per hour, their fast growth rate as evidenced in Table 3 may imply a significant contribution to compensation growth.

Our estimates of the impact of stock options on the growth in $C P H$ are given in Table 4. For reference, we give the annual growth in $\mathrm{CPH}$ (column 2). We start by recomputing the growth rate in each year removing from total compensation an estimate of overall NQSO realizations in public companies. We do this using two different approaches. First, we do a simple extrapolation from the ExecuComp sample which requires no estimation (column 3). For each year, we calculate the average stock option realizations per employee based on all firms in the ExecuComp sample. We then gross this up to cover all public firms by assuming that all workers in public firms that are not in the ЕхесиСотр sample realized this average value of stock options. Our second (and preferred) approach is to use our estimates from Table 2 to predict stock option realizations for COMPUSTAT firms that are not in the ExecuComp sample (column 4). In both cases, we subtract the implied income from NQSO realizations from total

\footnotetext{
${ }^{24}$ Our estimates of the value of stock options per employee are likely to be conservative given our assumption of no stock option use by privately held firms.
} 
compensation in that year, and we divide by total hours to recompute $C P H$ net of the effect of stock option realizations. ${ }^{25}$

The actual growth in nominal $C P H$ accelerated from around 2 percent in 1995 to 5 percent in 1998. This is consistent with the tightening of the labor market during this time period. Notice, however, that if we removed the contribution of stock option realizations from public companies using our second approach, growth in $C P H$ in 1998 would have been 4.3 percent. Stock option realizations appear to have contributed around 0.7 percentage points to the growth in $\mathrm{CPH}$ in 1998. This illustrates the sizeable impact that a fast growing segment of compensation can have on overall $C P H$ growth rates, even when that segment still accounts for a small fraction of overall compensation.

Having removed the influence of current stock option realizations from $C P H$, we now recalculate the growth in $\mathrm{CPH}$ including the estimated cash value of new grants of ESOs (column 5). This last adjustment yields a CPH measure which should more accurately reflect current labor market conditions. We add the cash value of new ESO grants to total compensation less stock option realizations in that year, and we divide by total hours to recompute $C P H$.

Does the peculiar way in which stock options enter $C P H$ offer an explanation for the second pay puzzle? To answer this, we examine the implied growth rate of $C P H$ in 1998 and 1999 where we have removed stock option realizations and included new stock option grants. Despite continued tightening of labor markets in 1999, actual CPH deaccelerated from its 1998 growth rate [from 5.08 percent in 1998 to 4.64 percent in 1999]. However, when we look at our adjusted $\mathrm{CPH}$ measure, we find that it continued to accelerate through 1999 [from 4.95 percent in 1998 to 5.05 percent in 1999]. ${ }^{26}$ The dropoff in the pace of actual $C P H$ in 1999, therefore, can

\footnotetext{
${ }^{25}$ To assess the reliability of our estimates we also report monte carlo standard errors. These were computed by simulating draws of new coefficient estimates from the stock option grant and realizations estimations, recalculating the all of the results, and repeating this process 1,000 times. The reported standard errors are the standard deviations of the sample distribution of results for each statistic reported in the table.

${ }^{26}$ The adjusted $\mathrm{CPH}$ growth rate is sensitive to the assumptions we made along the way. For example, if we assume that the cash value of new grants is 60 percent (40 percent) of the Black-Scholes value, then the adjusted CPH growth rate in 1999 is 5.13 percent (4.97 percent).
} 
potentially be explained by the rapid increase in new stock option grants in this year relative to current realizations from prior year grants.

An implication of this finding is that stock options may be changing the traditional relationship between unemployment rates and pay measures. If firms increasingly use stock options as a substitute for wage and salary increases in order to attract and retain workers in a tight labor market, then the impact of tight labor markets will either be muted in the data [for those pay measures such as the Employment Cost Index that do not reflect stock options], or it will show up with a several year lag [for pay measures like $C P H$ that reflect realizations ] due to the vesting requirements for stock options.

The most comparable effort in the literature at assessing the impact of stock options on aggregate pay measures is Lebow et al (1999). They construct a sample of employee stock option plans for 125 S\&P 500 firms. Their sample covers the years 1994 to 1998. Using the details of the option grants, they calculate modified Black-Scholes values for the new grants in each year. They find that over their sample period, the average stock option grant value per employee grew at a 31 percent annual rate. This accords well with our data which indicate an average annual growth rate over this period of 33 percent. Assuming that all workers at public companies experienced the same rate of growth in stock option grants, they calculate that treating stock option grants as compensation on the grant date would have added roughly a quarter percentage point to growth in the Employment Cost Index.

\section{Additional Implications}

Our analysis indicates that while employee stock options still represent a small fraction of total compensation in the U.S., they have grown rapidly over the past few years. The result, as shown in Table 4, is that the recent growth of $C P H$ has been significantly impacted by the behavior of stock option grants and realizations. These findings have several implications which we now discuss.

If the trend in the use of stock options continues, a consequence is that $C P H$ growth is likely to be more variable in the future than it has been in the past. As we saw from the earlier analysis, current stock option realizations depend to a great extent on the firm's recent stock 
performance. Swings in the equity markets will generate swings in stock option realizations that are likely to exceed the underlying movements in base wage and salary income. This increased volatility implies that discerning trend changes in $C P H$ growth will be more difficult.

Understanding the impact of stock options on $C P H$ is critical to making the correct inference on the underlying pay trends. This underscores the need for more accurate and timely data on stock options.

An increased reliance on stock options may also increase overall pay flexibility in the U.S. labor market. A variety of arguments have been put forward as to why employers are reluctant to impose nominal wage cuts on workers during adverse times [see Lebow et al (1995), Groshen and Schweitzer (1996), Card and Hyslop (1997) and McLaughlin (1999)]. A corollary is that some inflation is good for labor market efficiency in that it allows for real wage reductions even in the absence of nominal wage reductions. Stock options by design build in downward pay flexibility. As noted earlier, the typical NQSO is issued with the strike price equal to the market price. If the firm does not produce equity gains during the vesting period, then the options will remain out-of-the-money and will not be exercised by the workers. ${ }^{27}$ This added pay flexibility may help to relax any constraints imposed by nominal wage rigidities that may exist in the base wage and salary components of pay. As a consequence, the labor market may be able to operate efficiently at a lower steady-state rate of inflation.

Finally, stock options may strengthen the link between pay and performance. Hall and Liebman (1998) argue that the increasing importance of stock options in executive pay has been the primary determinant of the increased sensitivity of executive compensation to firm performance. As stock options filter down through the salary ranks, an increasing segment of a firm's salary liability will become linked to firm performance. This restructuring of the wage contract between a firm and its workers may be contributing to the upturn in labor productivity [see Black \& Lynch (2000)].

\footnotetext{
${ }^{27}$ Firms, however, may reprice their employee stock options and/or issue new stock option grants in order to restore incentives. See Carter and Lynch (2000) for FASB reporting of repricing of ESOs.
} 


\section{Conclusions}

In this paper, we try to resolve one of the aggregate pay puzzles in the 1990s by exploring the impact that stock options are having on the growth of $C P H$. The actual growth in nominal CPH accelerated from around 2 percent in 1995 to 5 percent in 1998. As labor markets continued to tighten in 1999, the growth of $C P H$ paradoxically slowed. When we recalculate $C P H$ growth to reflect the value of current stock option grants and not current realizations, we find that our adjusted $\mathrm{CPH}$ measure accelerated in each year from 1995 to 1999. The timing of when stock options are picked up in $C P H$, then, does help to explain the pay puzzle of the late 1990s.

\section{References}

Bell, Linda, and Douglas Kruse. "Evaluating ESOPs, Profit-Sharing and Gain Sharing Plans in U.S. Industries: Effects on Worker and Company Performance." Submitted to: The Office of the American Workplace, U.S. Department of Labor, May, 1995.

------, and David Neumark. "Lump-Sum Payments and Profit-Sharing Plans in the Union Sector of the United States Economy." Economic Journal 103 (May 1993): 602-619.

Bizjak, John M., James A. Brickley, and Jeffrey L. Coles. "Stock-based Incentive Compensation and Investment Behavior." Journal of Accounting and Economics 16 (Jan.-April-July 1993): 349-372.

Black, Sandra, and Lisa M. Lynch. "What's Driving the New Economy: The Benefits of Workplace Innovation." Working Paper No. 7479. NBER, January, 2000.

Card, David, and Dean Hyslop. "Does Inflation "Grease the Wheels of the Labor Market?"." In Reducind Inflation: Motivation and Strategy, edited by Christina Romer and David Romer, 114-121. National Bureau of Economic Research Studies in Business Cycles, vol. 30, University of Chicago Press, 1997.

Carter, Mary Ellen, and Luann J. Lynch. "Does Accounting Affect Economic Behavior? Evidence from Stock Options Repricing." Working Paper. Accounting Department, Columbia University, 2000.

Cohn, Laura. "The Hidden Costs of Stock Options." Business Week, December 6 1999, 44.

Core, John, and Wayne Guay. "The Use of Equity Grants to Manage Optimal Equity Incentive Levels." Working Paper. The Wharton School, University of Pennsylvania, June, 1999.

------, and Wayne Guay. "Stock Option Plans for Non-Executive Employees." Working Paper. University of Pennsylvania, The Wharton School, January, 2000.

Duca, John V. "The New Labor Paradigm: More Market-Responsive Rules of Work and Pay." Southwest Economy: 6-8.

Epstein, Gene. "Sure, Options Pay Represents Funny Money, But Its Earnings Impact is Less Than Critics Claim." Barrons, October 61999.

Farber, Henry S. "The Changing Face of Job Loss in the United States, 1981-1995." Brookings Papers on Economic Activity Microeconomics, no. 0 (1997): 55-128. 
Graham, John, john.graham@duke.edu. "Simulated Tax Rates -- Order Form."

Http://www.duke.edu/ jgraham/taxform.html.

"Debt and the Marginal Tax Rate." Journal of Financial Economics 41 (May 1996): 41-73.

Groshen, Erica, and Mark Schweitzer. "The Effects of Inflation on Wage Adjustments in

Firm-Level Data: Grease or Sand?" Working Paper. Federal Reserve Bank of New York, January, 1996.

Hall, Brian J., and Jeffrey B. Liebman. "Are CEOs Really Paid Like Bureaucrats?" Quarterly Journal of Economics 113 (August 1998): 653-691.

------, and Jeffrey B. Liebman. "The Taxation of Executive Compensation." In Tax Policy and the Economy, edited by James Poterba. Cambridge, MA, MIT press, 2000.

Hewitt Associates LLC. TCM Data, 1998.

Huddart, Steven, and Mark Lang. "Employee Stock Options Exercises: An Empirical Analysis." Journal of Accounting and Economics 21 (February 1996): 5-43.

John, Teresa A., and Kose John. "Top-Management Compensation and Capital Structure." Journal of Finance 48 (July 1993): 949-974.

Kulatilaka, Nalin, and Alan J. Marcus. "Valuing Employee Stock Options." Financial Analysts Journal 50 (Nov/Dec 1994): 46-56.

Lambert, Richard, and David F. Larcker. "An Analysis of the Use of Accounting and Market Measures of Performance in Executive Compensation Contracts." Journal of Accounting Research 25, Supplement (1987): 85-125.

------, David F. Larcker, and Robert E. Verrecchia. "Portfolio Considerations in Valuing Executive Compensation." Journal of Accounting Research 29 (Spring 1991): 129-149.

Lebow, David, Louise Sheiner, Larry Slifman, and Martha Starr-McCluer. "Recent Trends in Compensation Practices." Finance and Economics Discussion Series No. 32. Federal Reserve Board, 1999.

------, David Stockton, and William Washer. "Inflation, Nominal Wage Rigidity, and the Efficiency of Labor Markets." Finance and Economics Discussion Series: 94-45. Board of Governors of the Federal Reserve System, October, 1995.

Manski, Charles F., and John D. Straub. "Worker Perceptions of Job Insecurity in the Mid-1990s: Evidence From the Survey of Economic Expectations." Journal of Human Resources 35, no. 3 (2000): 447-479.

McLaughlin, Kenneth J. "Are Nominal Wage Changes Skewed Away From Wage Cuts?" Federal Reserve Bank of St. Louis: Review 81 (May/June 1999): 117-132.

Mehran, Hamid. "Executive Incentive Plans, Corporate Control, and Capital Structure." Journal of Financial and Quantitative Analysis 27 (December 1992): 539-560.

------, and Joseph Tracy. "The Effect of Employee Stock Ownership Plans on Firm Performance." Working Paper. Federal Reserve Bank of New York, 1998.

------, and David Yermack. "Compensation and Top Management Turnover." Working Paper. Stern Business School, New York University, 1999.

Murphy, Kevin J. "Executive Compensation." In Handbook of Labor Economics, edited by Orley C. Ashenfelter and David Card. Amsterdam, North-Holland, 1999.

Smith, Clifford W., and Ross L. Watts. "The Investment Opportunity Set and Coporate Financing, Dividend, and Compensation Policies." Journal of Financial Economics 32, no. 3 (1992): 263-292. 
U.S. Department of Labor, Bureau of Labor Statistics. Pilot Survey on the Incidence of Stock Options in Private Industry in 1999. October 11, 2000.

Yermack, David. "Do Corporations Award CEO Stock Options Effectively?" Journal of Financial Economics 39, no. 2 (1995): 237-269. 
Appendix A: Estimating the level of stock option realizations

We use a generalized Tobit framework for estimating a firm's stock option realizations. Let $I^{*}$ denote a latent index for the propensity for a firm's workers to realize their vested options in a given year. Let $R^{*}$ denote desired realizations, and $R$ actual realizations. We assume that $I^{*}$ and $\ln$ $R^{*}$ have a continuous distribution, while $\ln R$ has a censored distribution.

$$
\begin{aligned}
& I_{i t}^{*}=Z_{i t} \gamma+\varepsilon_{1 i t}, \\
& \ln R_{i t}^{*}=X_{i t} \beta+\varepsilon_{2 i t}, \\
& \left(\begin{array}{l}
\varepsilon_{1} \\
\varepsilon_{2}
\end{array}\right) \sim \mathrm{N}(0, \Sigma), \quad \sum=\left[\begin{array}{ll}
1 & \sigma_{12} \\
\cdot & \sigma_{2}^{2}
\end{array}\right], \\
& \ln R_{i t}=\begin{array}{l}
\ln R_{i t}^{*} \quad \text { if } I_{i t}^{*}>0 \\
0 \quad \text { otherwise }
\end{array}
\end{aligned}
$$

The probability of a firm having positive stock option realizations in a year is given by $\mathrm{F}\left(\mathrm{Z}_{\mathrm{t}}\right.$ ?). Given the assumed normality of the two error terms, the observed stock option realizations have the following conditional mean.

$$
\mathrm{E}\left(\ln R_{i t} \mid \ln R_{i t}^{*}>0\right)=X_{i t} \beta+\sigma_{12} \frac{\phi\left(Z_{i t} \gamma\right)}{\Phi\left(Z_{i t} \gamma\right)},
$$

where $\mathrm{f}$ and $\mathrm{F}$ are the standard normal density function and cumulative density functions, respectively. The expected unconditional stock option realizations are given by the probability of observing positive realizations in a year multiplied by the expected conditional magnitude of the realizations.

$$
E\left(\ln R_{i t} \mid Z_{i t}, X_{i t}\right)=\Phi\left(Z_{i t}\right)\left[X_{i t} \beta+\sigma_{12} \frac{\phi\left(Z_{i t} \gamma\right)}{\Phi\left(Z_{i t} \gamma\right)}\right]
$$

We estimate this model in two steps. First, we estimate the ? parameters using a Probit model. Using these estimates, we calculate the variable $f / F$ for each observation with a positive realization. We then estimate the $\beta$ parameters by regressing the log positive realizations on our $X$ variables and $\mathrm{f} / \mathrm{F}$. 


\begin{tabular}{|c|c|c|c|c|c|c|}
\hline Description & Source & Method of Calculation & Mean & Std Dev & Min & Max \\
\hline \multicolumn{7}{|c|}{ Note: Compustat item numbers in Brackets } \\
\hline \multicolumn{7}{|l|}{ Grants Regression } \\
\hline Total grant value (\$ 000's) & Execucomp & Grants to top $5 *(100 / \%$ of grants to top 5$)$ & 31,378 & 356,183 & 15 & $14,200,000$ \\
\hline Log total grant value & Execucomp & & 8.78 & 1.59 & 2.74 & 16.47 \\
\hline Return on assets, 1 year lag & Compustat & $\begin{array}{l}\text { (Operating income before depreciation }[13]+ \\
\text { interest expense [15]) / (total assets [6]) }\end{array}$ & 0.16 & 0.11 & -1.55 & 0.97 \\
\hline Employment (000's) & Compustat & {$[29]$} & 17.99 & 49.83 & 0.01 & 825.00 \\
\hline Log employment & Compustat & $\ln ([29])$ & 1.49 & 1.70 & -4.96 & 6.72 \\
\hline Total assets $(\$ 000,000 ' s)$ & Compustat & [6] & 5,109 & 21,675 & 14 & 668,641 \\
\hline Log total assets & Compustat & $\ln ([6])$ & 6.96 & 1.63 & 2.62 & 13.41 \\
\hline Leverage ratio & Compustat & Total long term debt [9] / total assets [6] & 0.19 & 0.16 & 0.00 & 1.75 \\
\hline $\begin{array}{l}\text { Market value / book value, } \\
1 \text { year lag }\end{array}$ & Compustat & $\begin{array}{l}\text { (Price close calendar year }[24] * \text { shares } \\
\text { outstanding }[25]+\text { total assets }[6]-\text { common } \\
\text { equity }[60]) /(\text { total assets }[6])\end{array}$ & 2.20 & 2.08 & 0.48 & 45.33 \\
\hline $\begin{array}{l}\text { Standard deviation of stock } \\
\text { returns, } 1 \text { year lag }\end{array}$ & $\begin{array}{l}\text { CRSP or } \\
\text { Campbell \& } \\
\text { Lettau data }\end{array}$ & $\begin{array}{l}\text { Firm level (CRSP) data if available, otherwise } \\
\text { industry-level (Campbell \& Lettau, Journal of } \\
\text { Finance, forthcoming) data used }\end{array}$ & 0.02 & 0.01 & 0.00 & 0.09 \\
\hline $\begin{array}{l}\text { Number of years since stock first } \\
\text { traded publicly }\end{array}$ & CRSP & data year minus year stock first publicly traded & 13.60 & 9.85 & 0.00 & 30.00 \\
\hline Net operating loss & Compustat & 1 if $[52]>0 ; 0$ if $[52]=0$ & 0.31 & 0.39 & 0.00 & 1.00 \\
\hline \multicolumn{7}{|l|}{ Probit - Positive Realizations } \\
\hline $\begin{array}{l}\text { Total realized option value, } \quad(\$ \\
000 \text { 's })\end{array}$ & Execucomp & $\begin{array}{l}\text { Realized value for top } 5 *(100 / \% \text { of grants to } \\
\text { top } 5), 2 \text { year lag }\end{array}$ & 6,492 & 12,693 & -2 & 72,047 \\
\hline Log total realized option value & Execucomp & & 5.37 & 4.02 & 0.000 & 11.185 \\
\hline Employment, (\$ 000's) & Compustat & {$[29]$} & 16.79 & 45.34 & 0.005 & 756.300 \\
\hline Log employment & Compustat & $\ln ([29])$ & 1.53 & 1.60 & -5.30 & 6.63 \\
\hline
\end{tabular}




\begin{tabular}{|c|c|c|c|c|c|c|}
\hline $\begin{array}{r}\text { Description } \\
\end{array}$ & Source & Method of Calculation & Mean & Std Dev & Min & Max \\
\hline Leverage ratio & Compustat & Total long term debt [9] / total assets [6] & 0.19 & 0.16 & -0.04 & 1.72 \\
\hline Market value / book value & Compustat & $\begin{array}{l}\text { (Price close calendar year }[24] * \text { shares } \\
\text { outstanding }[25]+\text { total assets }[6]-\text { common } \\
\text { equity }[60]) /(\text { total assets }[6])\end{array}$ & 1.98 & 1.49 & 0.49 & 15.77 \\
\hline $\begin{array}{l}\text { Standard deviation of stock } \\
\text { returns }\end{array}$ & $\begin{array}{l}\text { CRSP or } \\
\text { Campbell \& } \\
\text { Lettau Data }\end{array}$ & $\begin{array}{l}\text { Firm level (CRSP) data if available, otherwise } \\
\text { industry-level (Campbell \& Lettau) data used }\end{array}$ & 0.02 & 0.01 & 0.01 & 0.20 \\
\hline $\begin{array}{l}\text { Percent increase of stock returns } \\
\text { over previous two years }\end{array}$ & CRSP & & 0.47 & 1.08 & -0.99 & 18.95 \\
\hline Log total grants, 2 year lag & $\begin{array}{l}\text { Execucomp or } \\
\text { forecast }\end{array}$ & $\begin{array}{l}\text { Execucomp data if available, otherwise forecast } \\
\text { is used }\end{array}$ & 8.41 & 1.40 & 2.74 & 13.51 \\
\hline \multicolumn{7}{|l|}{ Realized Truncated Regression } \\
\hline $\begin{array}{l}\text { Total realized option value, } \quad(\$ \\
000 \text { 's })\end{array}$ & Execucomp & $\begin{array}{l}\text { Realized value for top } 5 *(100 / \% \text { of grants to } \\
\text { top } 5), 2 \text { year lag }\end{array}$ & 9,602 & 14,439 & 0 & 72,047 \\
\hline Log total realized option value & Execucomp & & 7.94 & 1.86 & 0.34 & 11.19 \\
\hline Employment, (000's) & Compustat & [29] & 18.49 & 47.95 & 0.04 & 756.30 \\
\hline Log employment & Compustat & $\ln ([29])$ & 1.63 & 1.60 & -3.30 & 6.63 \\
\hline Leverage ratio & Compustat & Total long term debt [9] / total assets [6] & 0.18 & 0.15 & -0.04 & 1.72 \\
\hline Market value / book value & Compustat & $\begin{array}{l}\text { (Price close calendar year }[24] * \text { shares } \\
\text { outstanding }[25]+\text { total assets }[6]-\text { common } \\
\text { equity }[60]) /(\text { total assets }[6])\end{array}$ & 2.13 & 1.62 & 0.56 & 15.77 \\
\hline $\begin{array}{l}\text { Standard deviation of stock } \\
\text { returns }\end{array}$ & $\begin{array}{l}\text { CRSP or } \\
\text { Campbell \& } \\
\text { Lettau Data }\end{array}$ & $\begin{array}{l}\text { Firm level (CRSP) data if available, otherwise } \\
\text { industry-level (Campbell \&Lettau) data used }\end{array}$ & 0.02 & 0.01 & 0.01 & 0.12 \\
\hline $\begin{array}{l}\text { Pct increase of stock returns over } \\
\text { previous two years }\end{array}$ & CRSP & & 0.60 & 1.18 & -0.95 & 18.95 \\
\hline Log total grants, 2 year lag & $\begin{array}{l}\text { Execucomp or } \\
\text { forecast }\end{array}$ & $\begin{array}{l}\text { Execucomp data if available, otherwise forecast is } \\
\text { used }\end{array}$ & 8.50 & 1.38 & 2.74 & 13.51 \\
\hline Mills Ratio & Probit Model & $\varphi(\mathrm{Xb}$ from probit $) / \Phi(\mathrm{Xb}$ from probit $)$ & 0.46 & 0.24 & 0.06 & 1.91 \\
\hline
\end{tabular}


Figure 1. Labor Market Tightness and Nominal CPH Growth

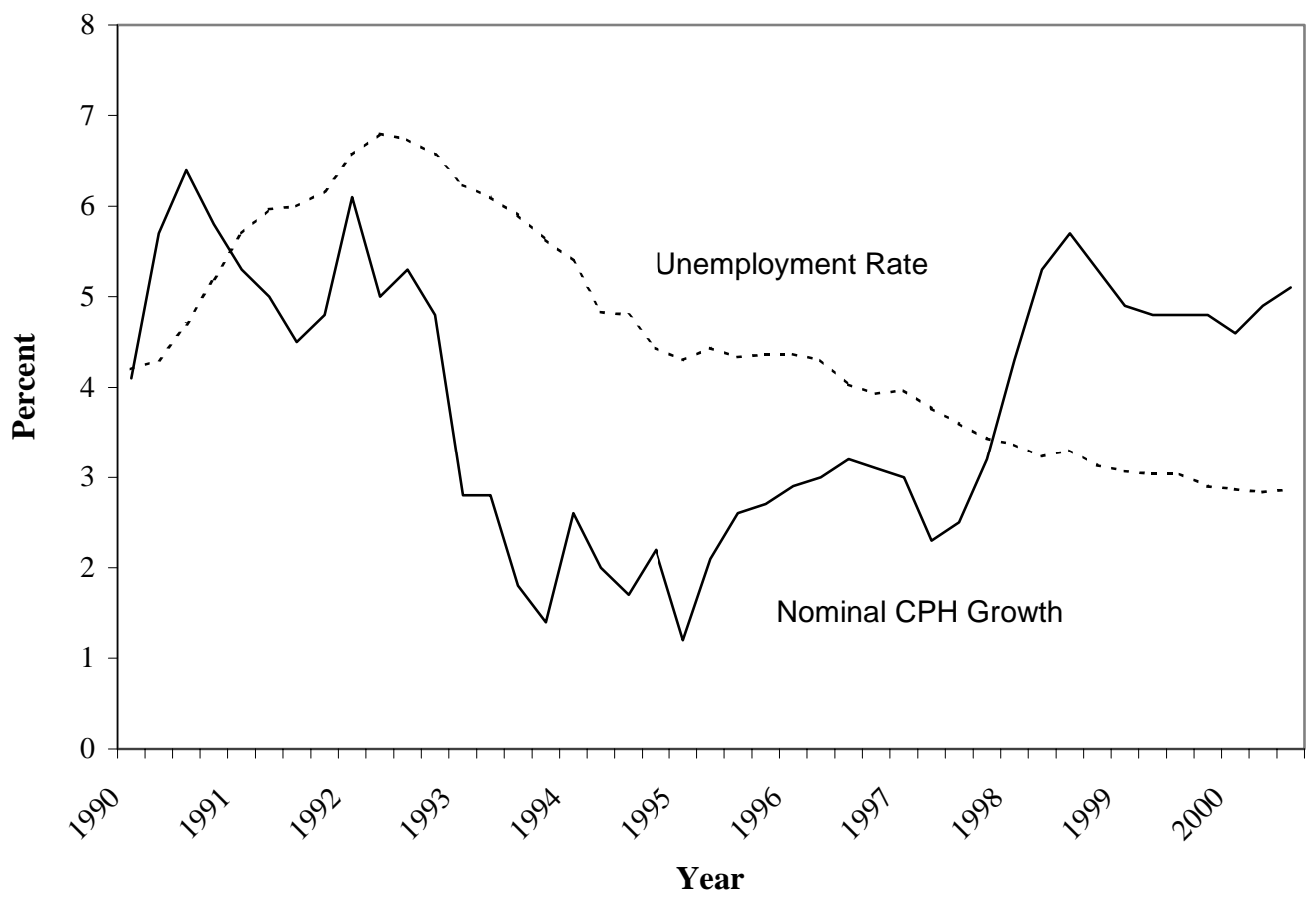


Figure 2. Ratio of Stock Option Grants and Realizations to Base Salary and Cash Bonus

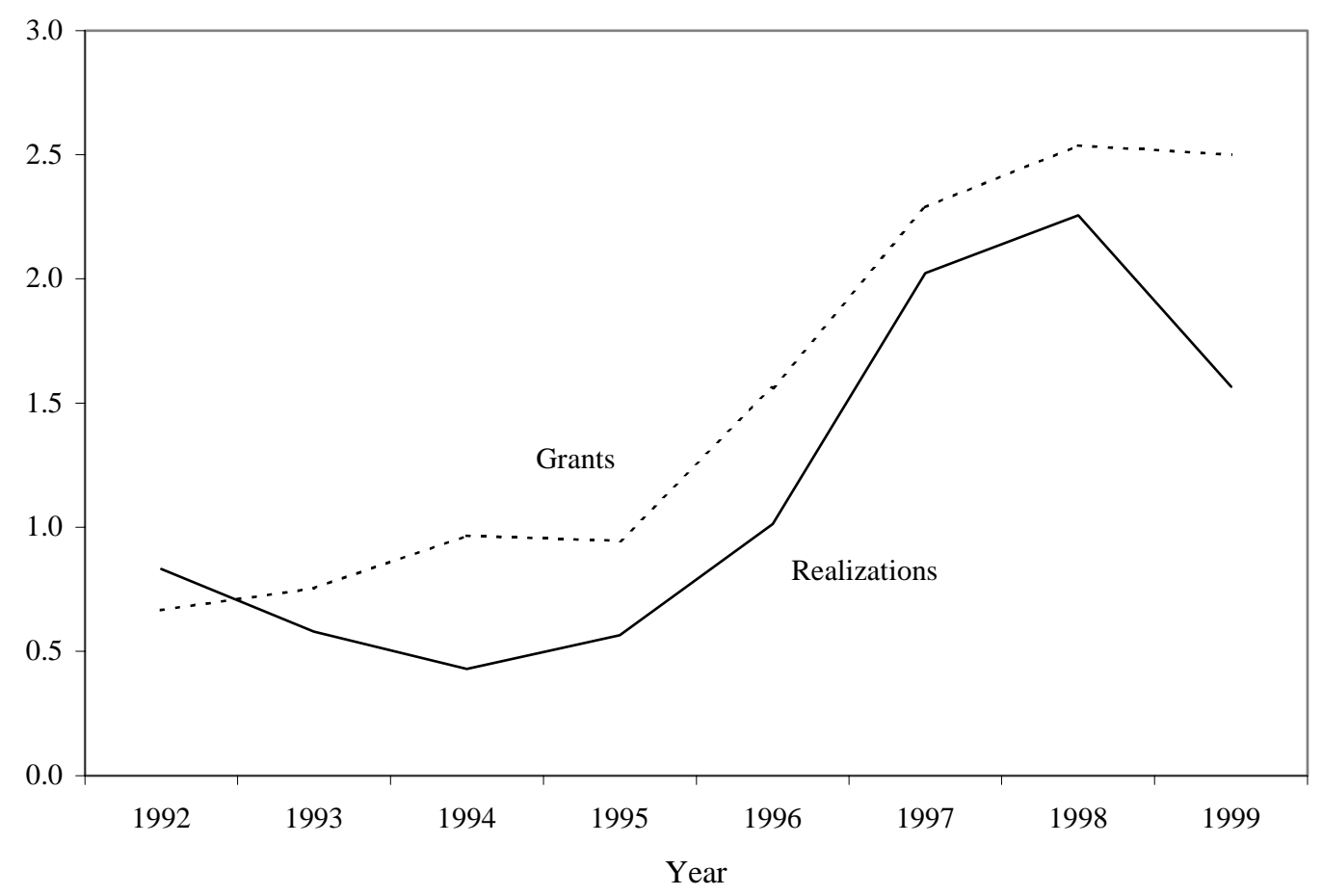


Figure 3. Percent of Stock Option Grants To Top 5 Executives

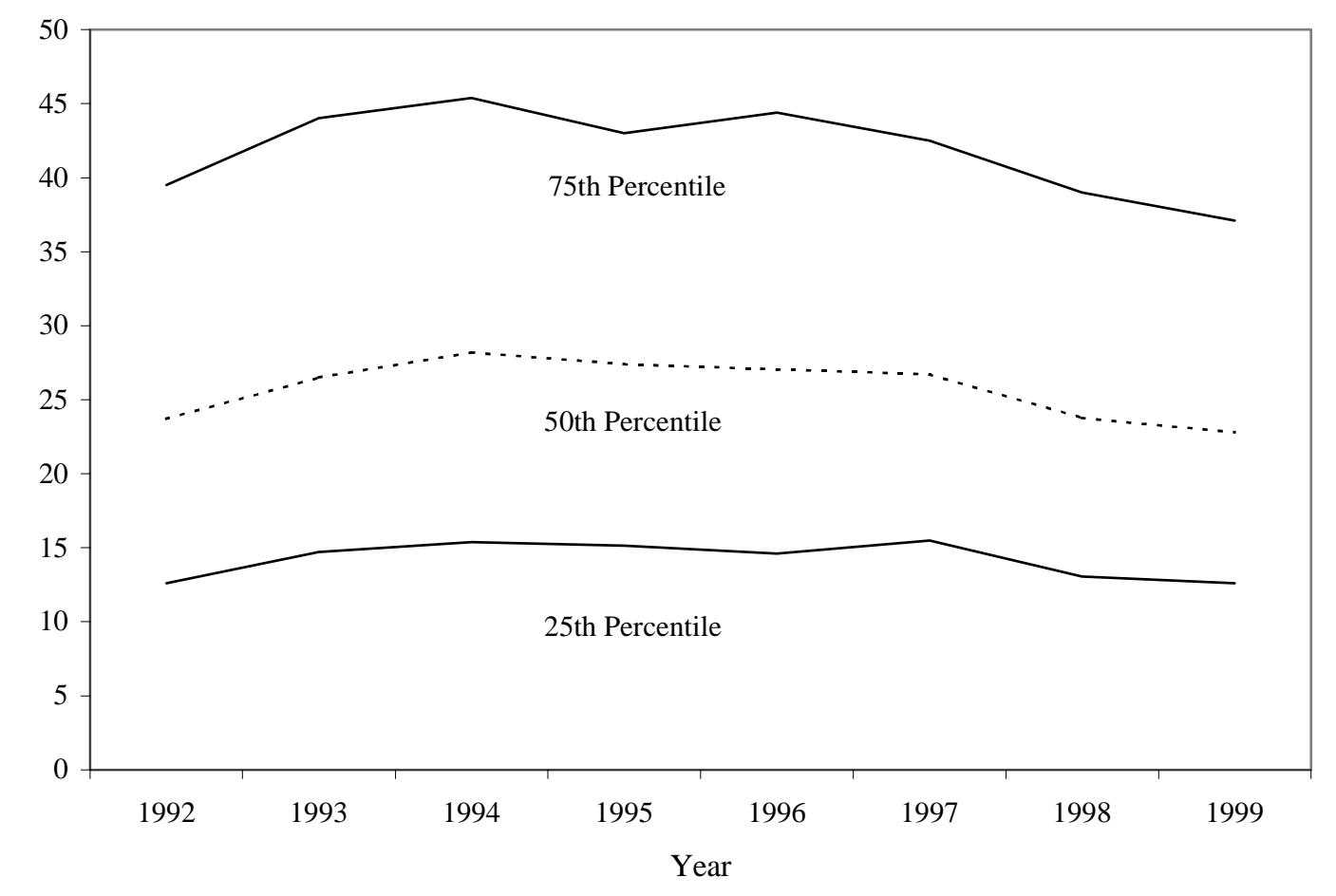


Table 1. Determinants of Stock Option Grants

\begin{tabular}{|c|c|c|c|}
\hline Variable & Percent Change & Variable & Percent Change \\
\hline Return on Assets & & Market-to-book value & \\
\hline $2^{\text {nd }}$ Quartile & $\begin{array}{c}-27.7^{* *} \\
(5.1)\end{array}$ & $2^{\text {nd }}$ Quartile & $\begin{array}{c}43.4^{* *} \\
(6.0)\end{array}$ \\
\hline $3^{\text {rd }}$ Quartile & $\begin{array}{c}-34.4^{* *} \\
(4.7)\end{array}$ & $3^{\text {rd }}$ Quartile & $\begin{array}{c}104.8^{* *} \\
(9.3)\end{array}$ \\
\hline $4^{\text {th }}$ Quartile & $\begin{array}{c}-39.1^{* *} \\
(4.5)\end{array}$ & $4^{\text {th }}$ Quartile & $\begin{array}{c}300.3^{* *} \\
(20.5)\end{array}$ \\
\hline Log Employment & & Stock return risk & \\
\hline $2^{\text {nd }}$ Quartile & $\begin{array}{c}5.3 \\
(15.6)\end{array}$ & $2^{\text {nd }}$ Quartile & $\begin{array}{l}-13.5 \\
(18.0)\end{array}$ \\
\hline $3^{\text {rd }}$ Quartile & $\begin{array}{c}3.3 \\
(15.5)\end{array}$ & $3^{\text {rd }}$ Quartile & $\begin{array}{c}-31.7^{* *} \\
(10.2)\end{array}$ \\
\hline $4^{\text {th }}$ Quartile & $\begin{array}{l}64.7^{* *} \\
(25.2)\end{array}$ & - $\quad 4^{\text {th }}$ Quartile & $\begin{array}{c}-23.3^{* *} \\
(11.2)\end{array}$ \\
\hline Log Assets & & Net Operating Loss & $\begin{array}{c}24.2^{* *} \\
(5.0)\end{array}$ \\
\hline $2^{\text {nd }}$ Quartile & $\begin{array}{c}89.1 \\
(94.4)\end{array}$ & Firm age (10 years) & $\begin{array}{c}-8.4^{* *} \\
(1.5)\end{array}$ \\
\hline $3^{\text {rd }}$ Quartile & $\begin{array}{c}343.1 \\
(221.8)\end{array}$ & Number of obs. & 8,182 \\
\hline $4^{\text {th }}$ Quartile & $\begin{array}{c}1,453.7^{*} \\
(779.7)\end{array}$ & R-square & 0.46 \\
\hline \multicolumn{4}{|l|}{ Leverage } \\
\hline $2^{\text {nd }}$ Quartile & $\begin{array}{l}-5.7 \\
(4.5)\end{array}$ & & \\
\hline $3^{\text {rd }}$ Quartile & $\begin{array}{c}-16.7^{* *} \\
(4.0)\end{array}$ & & \\
\hline $4^{\text {th }}$ Quartile & $\begin{array}{c}-26.6^{* *} \\
(3.8)\end{array}$ & & \\
\hline
\end{tabular}

Notes: OLS estimates of the percent changes in the Black-Scholes grant value are reported with standard errors given in parentheses. Two-digit industry and year effects are included in the specification. Sample is derived from ExecuComp and COMPUSTAT data.

${ }^{* *}$ Significant at the 5\% level.

${ }^{*}$ Significant at the $10 \%$ level. 


\begin{tabular}{|c|c|c|c|}
\hline Variable & $\begin{array}{l}\text { (1) } \\
\text { Probability of a } \\
\text { Positive Realization }\end{array}$ & $\begin{array}{c}(2) \\
\text { Expected Realizations } \\
\text { Conditional on a } \\
\text { Positive Realization }(\%)\end{array}$ & $\begin{array}{c}\text { (3) } \\
\text { Expected } \\
\text { Unconditional } \\
\text { Realization (\%) }\end{array}$ \\
\hline Grants lag 2-years & $\begin{array}{l}2.1^{* *} \\
(0.6)\end{array}$ & $\begin{array}{l}75.1^{* *} \\
(5.3)\end{array}$ & $\begin{array}{l}75.3^{* *} \\
(8.5)\end{array}$ \\
\hline $\begin{array}{l}\text { Cumulative 2-year stock } \\
\text { - } \quad 2^{\text {nd }} \text { Quartile }\end{array}$ & $\begin{array}{l}18.0^{* *} \\
(2.5)\end{array}$ & $\begin{array}{c}4.0 \\
(4.1)\end{array}$ & $\begin{array}{l}280.7^{* *} \\
(89.9)\end{array}$ \\
\hline $3^{\text {rd }}$ Quartile & $\begin{array}{l}28.2^{* *} \\
(2.5)\end{array}$ & $\begin{array}{l}89.9^{* *} \\
(22.9)\end{array}$ & $\begin{array}{l}1,153.0^{* *} \\
(328.6)\end{array}$ \\
\hline $4^{\text {th }}$ Quartile & $\begin{array}{l}32.9^{* *} \\
(2.5)\end{array}$ & $\begin{array}{l}205.3^{* *} \\
(37.3)\end{array}$ & $\begin{array}{l}2,541.0^{* *} \\
(750.3)\end{array}$ \\
\hline $\begin{array}{l}\text { Log Employment } \\
\cdot \quad 2^{\text {nd }} \text { Quartile }\end{array}$ & $\begin{array}{l}20.3^{* *} \\
(9.1)\end{array}$ & $\begin{array}{l}-38.5 \\
(27.7)\end{array}$ & $\begin{array}{c}274.4 \\
(310.1)\end{array}$ \\
\hline $3^{\text {rd }}$ Quartile & $\begin{array}{l}23.2^{* *} \\
(8.9)\end{array}$ & $\begin{array}{l}-25.5 \\
(32.9)\end{array}$ & $\begin{array}{c}432.7 \\
(432.5)\end{array}$ \\
\hline $4^{\text {th }}$ Quartile & $\begin{array}{l}27.5^{* *} \\
(8.9)\end{array}$ & $\begin{array}{l}-14.9 \\
(37.6)\end{array}$ & $\begin{array}{c}715.4 \\
(666.2)\end{array}$ \\
\hline $\begin{array}{l}\text { Leverage } \\
\qquad \quad 2^{\text {nd }} \text { Quartile }\end{array}$ & $\begin{array}{l}-0.3 \\
(2.5)\end{array}$ & $\begin{array}{c}7.4 \\
(11.3)\end{array}$ & $\begin{array}{c}2.9 \\
(23.5)\end{array}$ \\
\hline $3^{\text {rd }}$ Quartile & $\begin{array}{c}2.3 \\
(2.5)\end{array}$ & $\begin{array}{c}12.9 \\
(11.8)\end{array}$ & $\begin{array}{c}31.1 \\
(29.1)\end{array}$ \\
\hline $4^{\text {th }}$ Quartile & $\begin{array}{l}-2.0 \\
(2.7)\end{array}$ & $\begin{array}{c}2.2 \\
(11.9)\end{array}$ & $\begin{array}{l}-12.7 \\
(21.4)\end{array}$ \\
\hline $\begin{array}{l}\text { Market-to-book value } \\
\text { - } \quad 2^{\text {nd }} \text { Quartile }\end{array}$ & $\begin{array}{l}11.9^{* *} \\
(2.1)\end{array}$ & $\begin{array}{l}59.0^{* *} \\
(14.5)\end{array}$ & $\begin{array}{c}221.5^{* *} \\
(63.4)\end{array}$ \\
\hline $3^{\text {rd }}$ Quartile & $\begin{array}{l}21.7^{* *} \\
(2.2)\end{array}$ & $\begin{array}{l}118.1^{* *} \\
(21.4)\end{array}$ & $\begin{array}{l}772.8^{* *} \\
(204.6)\end{array}$ \\
\hline $4^{\text {th }}$ Quartile & $\begin{array}{l}26.5^{* *} \\
(2.3)\end{array}$ & $\begin{array}{l}223.1^{* *} \\
(34.8)\end{array}$ & $\begin{array}{l}1,653.2^{* *} \\
(467.8)\end{array}$ \\
\hline $\begin{array}{l}\text { Stock return risk } \\
\text { - } \quad 3^{\text {rd }} \text { Quartile }\end{array}$ & $\begin{array}{l}5.9^{* *} \\
(2.1)\end{array}$ & $\begin{array}{c}11.4 \\
(10.4)\end{array}$ & $\begin{array}{l}77.4^{* *} \\
(39.3)\end{array}$ \\
\hline Number of observations & $5,189^{\mathrm{a}}$ & 3,508 & $5,189^{\mathrm{a}}$ \\
\hline
\end{tabular}

Notes: Generalized Tobit marginal effects are reported with standard errors given in parentheses. Twodigit industry and year effects are included in the specification. Sample is derived from ExecuСomp and COMPUSTAT data.

a Sample size is smaller than in Table 1 due to inclusion of lag grants variable.

${ }^{* *}$ Significant at the 5\% level.

* Significant at the $10 \%$ level. 
Table 3. Trends in Compensation, Stock Option Grants and Stock Option Realizations

\begin{tabular}{|c|c|c|c|c|c|}
\hline Year & $\begin{array}{l}\text { Compensation } \\
(\% \text { Change })^{1}\end{array}$ & $\begin{array}{l}\text { Stock Option } \\
\text { Realizations } \\
(\% \text { Change })^{2}\end{array}$ & $\begin{array}{l}\text { Realizations } \\
\text { as a \% of } \\
\text { Compensation }\end{array}$ & $\begin{array}{l}\text { Stock Option } \\
\text { Grants } \\
(\% \text { Change })^{3}\end{array}$ & $\begin{array}{c}\text { Grants } \\
\text { as a } \% \text { of } \\
\text { Compensation }\end{array}$ \\
\hline & \multicolumn{5}{|c|}{ Panel A: Aggregate } \\
\hline 1995 & $\begin{array}{c}3,488.1 \\
(4.6)\end{array}$ & $\begin{array}{c}38.6 \\
(84.2)\end{array}$ & 1.1 & $\begin{array}{l}26.5 \\
(7.3)\end{array}$ & 0.8 \\
\hline 1996 & $\begin{array}{c}3,656.9 \\
(4.8)\end{array}$ & $\begin{array}{l}49.8 \\
(28.8)\end{array}$ & 1.4 & $\begin{array}{c}39.6 \\
(49.6)\end{array}$ & 1.1 \\
\hline 1997 & $\begin{array}{c}3,911.1 \\
(7.0)\end{array}$ & $\begin{array}{c}71.6 \\
(43.8)\end{array}$ & 1.8 & $\begin{array}{c}55.6 \\
(40.3)\end{array}$ & 1.4 \\
\hline 1998 & $\begin{array}{c}4,214.7 \\
(7.8)\end{array}$ & $\begin{array}{l}109.3 \\
(52.7)\end{array}$ & 2.6 & $\begin{array}{c}86.7 \\
(55.9)\end{array}$ & 2.1 \\
\hline \multirow[t]{2}{*}{1999} & $\begin{array}{l}4,489.1 \\
(6.5)\end{array}$ & $\begin{array}{l}116.0 \\
(6.1)\end{array}$ & 2.6 & $\begin{array}{l}110.5 \\
(27.5)\end{array}$ & 2.5 \\
\hline & \multicolumn{5}{|c|}{ Panel B: Per Worker ${ }^{4}$} \\
\hline 1995 & $\begin{array}{c}35,631 \\
(1.5)\end{array}$ & $\begin{array}{c}395 \\
(78.8)\end{array}$ & 1.1 & $\begin{array}{l}271 \\
(4.2)\end{array}$ & 0.8 \\
\hline 1996 & $\begin{array}{c}36,498 \\
(2.4)\end{array}$ & $\begin{array}{c}497 \\
(25.9)\end{array}$ & 1.4 & $\begin{array}{c}395 \\
(46.2)\end{array}$ & 1.1 \\
\hline 1997 & $\begin{array}{c}37,925 \\
(3.9)\end{array}$ & $\begin{array}{c}694 \\
(39.7)\end{array}$ & 1.8 & $\begin{array}{c}539 \\
(36.3)\end{array}$ & 1.4 \\
\hline 1998 & $\begin{array}{c}39,749 \\
(4.8)\end{array}$ & $\begin{array}{l}1,032 \\
(48.6)\end{array}$ & 2.6 & $\begin{array}{c}817 \\
(51.7)\end{array}$ & 2.1 \\
\hline 1999 & $\begin{array}{c}41,333 \\
(4.0)\end{array}$ & $\begin{array}{l}1,068 \\
(3.6)\end{array}$ & 2.6 & $\begin{array}{l}1,018 \\
(24.5)\end{array}$ & 2.5 \\
\hline
\end{tabular}

Notes: Stock option realizations and grants are estimates based on Execucomp and COMPUSTAT data. Percent changes from the prior year are presented in parentheses.

${ }^{1}$ Private nonfarm business sector, $\$$ billions.

${ }^{2}$ Public companies only - scaled by $82 \%$ to reflect NQSOs (estimated), $\$$ billions.

${ }^{3}$ Public companies only - scaled by $50 \%$ to reflect effective cash value (estimated), \$billions.

${ }^{4}$ Same sample and scaling as aggregate numbers, $\$$ dollars. 


\begin{tabular}{|c|c|c|c|c|}
\hline \multirow[b]{2}{*}{ Year } & \multirow[b]{2}{*}{$\begin{array}{c}\text { Actual } \\
\text { CPH Growth }\end{array}$} & \multicolumn{3}{|c|}{ Public Companies } \\
\hline & & $\begin{array}{l}\text { CPH Growth } \\
\text { less } \\
\text { realizations }^{1}\end{array}$ & $\begin{array}{l}\text { CPH Growth } \\
\text { less } \\
\text { realizations }^{2}\end{array}$ & $\begin{array}{c}\mathrm{CPH} \text { Growth less } \\
\text { realizations plus } \\
\text { grants }^{2}\end{array}$ \\
\hline 1995 & 2.09 & 1.41 & $\begin{array}{l}1.61 \\
(0.07)\end{array}$ & $\begin{array}{l}1.63 \\
(0.07)\end{array}$ \\
\hline 1996 & 3.07 & 2.78 & $\begin{array}{c}2.82 \\
(0.07)\end{array}$ & $\begin{array}{c}3.14 \\
(0.07)\end{array}$ \\
\hline 1997 & 3.52 & 3.12 & $\begin{array}{l}3.05 \\
(0.09)\end{array}$ & $\begin{array}{c}3.39 \\
(0.09)\end{array}$ \\
\hline 1998 & 5.08 & 3.79 & $\begin{array}{c}4.30 \\
(0.09)\end{array}$ & $\begin{array}{c}4.95 \\
(0.09)\end{array}$ \\
\hline 1999 & 4.64 & 3.31 & $\begin{array}{c}4.65 \\
(0.09)\end{array}$ & $\begin{array}{c}5.05 \\
(0.08)\end{array}$ \\
\hline
\end{tabular}

Notes: Private non-farm compensation per hour growth. Monte carlo standard errors based on 1,000 simulations are given in parentheses.

${ }^{1}$ Simple extrapolations based on ExecuComp data.

${ }^{2}$ Based on estimated models presented in Tables 2 and 3. 